\title{
Schleiermacher: God-consciousness and religious identity
}

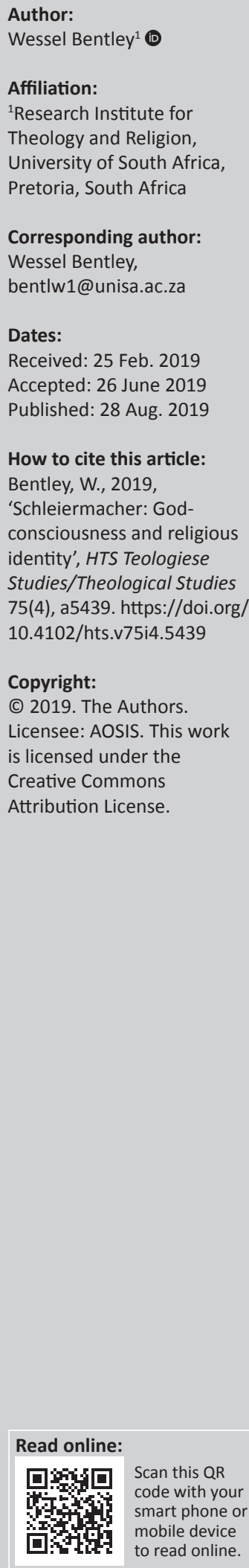

The world sees a shift in people's religious identity, moving away from the orthodox centre to either the extremes of religious fundamentalism or the religious identity of being 'spiritual, but not religious'. This article investigates the latter religious identity and asks whether Schleiermacher's theology may be of any value to it. The argument is that the context of disillusionment experienced during the Enlightenment and South Africa's transition to a post-secular constitutional democracy created the environment for a religious search beyond orthodoxy. The article then describes the tension between being conscious of the self and an awareness of dependence on the other, found in Schleiermacher's thinking and the notion of 'spirituality'. The article concludes by questioning how sin and evil, and the place of Jesus in Schleiermacher's theology and the stated form of religious identity, can be understood.

Keywords: Schleiermacher; God-consciousness; Religious identity; Doctrine; Spirituality.

\section{Introduction}

In this article, the notions of religious identity and Schleiermacher's 'God-consciousness' will be discussed.

I certainly do not wish to simply restate or describe Schleiermacher's theology, as this has been done before on numerous occasions and certainly with a much greater degree of competence than what I can offer. However, considering the 250-year celebration of Schleiermacher's birth, it would be fitting to engage with his thinking as it specifically relates to a growing form of religious identity, namely, where people state that they are 'spiritual, but not religious'. This article will describe how Schleiermacher's notion of 'God-consciousness' may be appealing to this form of religious identity on the following four counts:

1. a growing disillusionment with institutional religion

2. a consciousness of self and God

3. making sense of evil

4. the place of Jesus.

Before we progress to the discussion outlined above, it is worth noting that when we speak about religious identity, assuming a continuum where mainline religious identity is at the centre, there appears to be a general, global shift in two directions. These shifts are extremely challenging to the religious centre as they threaten the relevance and dominance of what was once considered orthodoxy. There appears to be a thinning out of the religious centre and a gravitation towards these two growing oppositional points; but I suggest that this should be explored as a topic for another study. To return to the shifts, the first is the obvious re-emergence of religious fundamentalism (see Emerson \& Hartman 2006). Religious fundamentalism can be characterised by the following traits, as described by Emerson and Hartman (2006:134):

- a defence of a religious tradition perceived to be under threat

- a focus on specific aspects of the tradition which then distinguishes its own tradition from that of the mainstream

- a dualistic approach to reality

- claims of absolutism and inerrancy

- the perception that history has a victorious end in favour of its own faith claims

- members are called and commissioned to defend the tradition

- clearly defined in- and outgroups

- authoritarian organisational structure

- behaviour of followers is clearly delineated to reflect the faith claims of the movement.

Note: Engaging Schleiermacher today: South African perspectives, sub-edited by Rian Venter (University of the Free State). 
Needless to say, religious fundamentalism has had a tremendous impact on world events, for example, the militant extremist activities of groups like ISIS (Islamic State of Iraq and Syria) on the one hand, and the rise of the 'Christian right' in countries like the USA, on the other hand. The second move, and perhaps on the other end of the spectrum, is the shift away from 'being religious' towards 'being spiritual'. It is on this perspective that I would like to focus in this article.

In a recent study, Bester and Müller (2017) showed that people increasingly identify as 'spiritual, but not religious'. In a similar study (see Faix, Hofmann \& Künkler 2015), there is an indication that there is a growing frustration and disillusionment with organised religion (the religious centre), especially among the youth in Europe. In both these studies, it is suggested that although people are increasingly uncomfortable with being labelled as belonging to a mainstream religious identity, they do not wish to surrender their religious identities altogether. Kourie states that this form of religious identity defines 'being spiritual' as an awareness of something greater than oneself without having to be caught up in the structures, power-play and politics of so-called organised religion. It 'refers therefore to the "ultimate values" that give meaning to our lives, whether or not they are religious or non-religious' (Kourie 2006:22).

It is my contention that this form of religious identity shows similarities to the notion of what Schleiermacher alluded to in his term 'God-consciousness'. Is it possible that Schleiermacher's views will find resonance with this form of religious identity? Let me explore this question on the following fronts.

\section{Setting the scene: A response to disillusionment with religion at the centre}

Of course, I cannot speak on behalf of the worldwide trend of 'spiritual, but not religious', but I can locate this conversation to the context in which I find myself, namely, speaking as a South African. I live in a country that has experienced great challenges in its transition from a claimed Christian state to that of a secular constitutional democracy. I would like to suggest that there are similarities between the current South African religious milieu (specifically Christian) and that of post-Enlightenment Europe. The latter is of course the space that Schleiermacher occupied. What is so significant about the Enlightenment?

The Enlightenment promoted four main ideas (Bowden \& Richardson 1983:179-180):

- reason as the true instrument to determine matters

- nature as the focal point and an appeal to what is considered to be 'natural'

- acceptance of the idea of progress

- rejection of tradition's authority.

Some of the by-products of the Enlightenment were elevated notions of self and a greater dependence on rationality, casting doubt on any system that suggests that human identity is to be found in the abstract, spiritual or perhaps metaphorical constructs of religious thought. Religion, in this period, must be rational to be acceptable; hence, the church's (in its various expressions) use of clichés to lead people blindly along set doctrines for the sake of the church's longevity no longer sufficed. It must be noted that Schleiermacher, the hailed 'father of modern theology', was a product of his time, a son of his theological and philosophical context (Root 1990:87-88). He responded to the Enlightenment's critique of religion by providing an apologia for religion that was grounded in rational reworkings of the church's doctrines (Lawson \& McCauley 1993:213). This is specifically illustrated in his discussion on the notions of sin and grace, as these doctrines called religion's credibility into question (Wyman 2005:129). ${ }^{1}$

Schleiermacher's own disillusionment with the set doctrines of the church and its blind belief reflected in a letter that he wrote to his father:

'Faith is the regalia of the Godhead', you say. Alas! dearest father, if you believe that without this faith no one can attain to salvation in the next world, nor to tranquillity in this - and such, I know, is your belief - oh! then pray to God to grant it to me, for to me it is now lost. I cannot believe that he who called himself the Son of Man was the true, eternal God; I cannot believe that his death was a vicarious atonement. (Gerrish 1984:25 quoted by Wikipedia 2018)

The tone of argument used in his Der Christliche Glaube (Schleiermacher 1986) is of specific interest. In this work, Schleiermacher presented an account of religious faith that reflects the contextual philosophical and theological swing towards rationalism. He did so not as a pious, religious traditionalist, trying to convince a world in which he himself felt to be a (Christian) stranger, but he spoke as a 'stranger' in the traditional religious wilderness, trying to make sense of what it means to be human, conscious, religious and credible in his specific context. Schleiermacher spoke to a context that had similar reservations about religious truths as what he had, addressing people who placed less and less trust in the structures of organised religion and rather depended on rational thinking (Schleiermacher 1995:26-27). ${ }^{2}$ Let us pause here for a moment in Schleiermacher's context and consider the context from where I speak.

I would venture to say that over the past two decades, the South African context displayed parallels in the positioning of religion in society compared to that of Schleiermacher's world. South Africa has moved from a sociopolitical system based on religion to a post-secular, constitutional democracy. What does this mean? During the apartheid regime,

1.The notions of 'sin' and 'grace', Wyman argues, were used as instruments to manipulate the masses by firstly instilling a sense that people's inherited sin became the causal foundation for God's alleged punitive actions. The church as custodian of God's grace was believed to be the chosen instrument to appease God and communicate God's grace. It is not hard to see how such a system could be abused and lead to social manipulation.

2.Schleiermacher (1995:26) described rationality as 'the crown of my existence', claiming - in concert with the Enlightenment - that rationality, even in religion, is the key that unlocks both virtue and happiness. A religious tradition devoid of the key that unlocks both virtue and happiness. A religious tradition devoid of
rationality should therefore be questionable in terms of both its integrity and its aims to instill virtue and happiness. 
Christianity (in particular) occupied a privileged position in society, especially the branch of Christianity that endorsed the prevailing political system. The strong reformed flavour of the dominant Christian voice held significant sway in being the authoritative measure in what was considered to be moral, evil, acceptable and unacceptable.

It is beyond doubt that this form of religious identity permeated every aspect of South African society. It strongly discriminated between 'in-groups' and 'out-groups', not only on political and ideological terms, but also on doctrinal and religious terms. On a personal note, I can recall how as a young, white boy attending Afrikaans schools, this brand of Christian belief was drilled into us through the religious education programme. It stamped into our minds the belief that we (as white people) were the chosen people, who were tasked by God to inhabit and develop this land. The religious undertones in the telling of stories like that of the Battle of Blood River further underscored the seemingly unquestionable religious significance of who we were and what we were called to do. The irrefutable religious wave further undergirded sociocultural movements such as Die Voortrekkers, to which I belonged. In my mind, the message was clear: we were God's children, the communists were to be thwarted, because they were the devil's children; God, Church, Country - this is where one's devotion laid. ${ }^{3}$ Furthermore, young men were to serve Volk en Vaderland through military conscription to defend the nation against the evils of this world. This was not only a matter of loyalty to the state but was also considered to be an expression of one's Christian faith and duty.

Luckily, I missed military conscription by a hair's breadth, but even if I had been called up, I would have become a conscientious objector. By this time, I had also long left Die Voortrekkers, because I was frowned on for asking an adult leader why there were no black children in our Kommando. Similarly, in 1994 when I suggested at school that we had to let go of the old South African flag and rather purchase the new one, I was made aware of my 'sin'; that I owed a debt of gratitude (to God) for the privilege of being white and that I should guard against the influences of 'die Swart gevaar'. Religion, with its set doctrines and its foundational understanding of what constituted being a white male in apartheid South Africa raised its voice in no uncertain terms. Although at that time, as indicated in footnote 3, I had moved on from this ideology, it was the accepted reality for many, if not most of white society.

With the inception of the Constitution of South Africa in 1996, the place of religion was redefined. The Constitution made provision for freedom of religion, freedom of association and freedom of expression (The Constitution of the Republic of South Africa 1996:5, 16, 18). It no longer provided religion with a special platform from where to speak.

3.It was only by the time I was 16 years old that I started to question the political status quo. Being a Methodist in upbringing (a denomination that opposed the perspectives perspectives that dominated my education and other activities. By 18 years of age I became convinced of the evils of apartheid and became very cynical of the brand of Christianity that dominated the country at the time.
Religion was now a voice among many voices; Christianity became a religion on equal measure with various other religions and now it found itself in uncharted territory, namely, having to legitimise itself in a post-secular constitutional democracy. No longer did its authoritative voice carry so much social weight.

One can imagine what such a dramatic shift must have been like, and it is still tremendously traumatic for a generation (and a sector of society) who held firm to the seemingly set authority of the church and its doctrines. It is no wonder that we still hear echoes of the past as groups label the move to a democratic society, not only as a betrayal by political leadership, but as a sell-out of a divine birth right and mandate.

It is significant that since the onset of democracy, membership in almost all the mainline denominations has been on a steady decline, while there has been a rise in the number of independent churches and faith expressions. The NG Kerk [Dutch Reformed Church] alone has seen a membership decline of almost 25\% in the last 19 years (Barnard 2019), despite its attempts (symbolic and pragmatic) to break with the past and reform its theology. In an interview with members and former members of the NG Kerk, people's disillusionment is evident: from those expressing that the church lied about apartheid and hence could lie about other issues to those who believe that the church's convictions about social concerns, such as LGBTIQ+ orientations and relationships, are outdated (Leonard 2012). One can deduce that potential members or former members of the church (not only the NG Kerk, but any mainline Christian denomination) will not subscribe to a theology of guilt, fear and obligation simply because this is what a Christian is supposed to believe. If people were to belong to a church, there needs to be a rational legitimisation of why one should in fact belong to the church or identify as a Christian at all. The dictum 'You need Jesus to be saved so that you can go to heaven ... and you need the church to help you' simply no longer works, that is, for those who choose the path of being spiritual, but not religious.

As for the rise of fundamentalism, this dictum is exactly what is presented and accepted. Those who choose not to engage rationally with their faith or context drift to prescriptive denominations, fundamentalist in belief; and in extreme cases may be prone to bizarre faith expressions such as eating grass to receive a blessing; inhaling insecticides to prove one's faith or to even surrender one's money in the hope for God's approval (mediated through the church and pastor, of course).

As with post-Enlightenment Europe, we find ourselves in a context where people who do not subscribe to religious fundamentalism need a legitimate, rational reason to subscribe to religious groups. Schleiermacher may not mean anything to Christian fundamentalists (except to be branded as a heretic), but I believe that those who venture away from 
the traditional centre to the 'spiritual, but not religious' may find resonance with his theological thinking.

So, 'how did Schleiermacher approach an understanding of God, religion, faith and self in this critical and sceptical environment?' or 'how did Schleiermacher make sense of religious faith himself?' and 'how does this resonate with religious expression today?'

\section{A consciousness of self and of God}

Francis Schüssler Fiorenza (Fiorenza 2000:13) is correct in stating that 'Schleiermacher is often singled out for attempting to isolate the essence of religion'. Schleiermacher opts for religion to be a mode of awareness, having no imposed conceptual, propositional dogmatic or doctrinal prescriptions. Reynolds (2005:159) emphasises this point by commenting that in The Christian Faith, Schleiermacher relies on propositions outside dogmatic formulations, namely, those borrowed from ethics, philosophy of religion and apologetics to describe religious identity. Schleiermacher is, in fact, very specific in the use of these propositions in that he uses propositions from ethics to describe the conception of the church (Schleiermacher 1986:5-31), philosophy of religion to describe the diversity of religious communions (Schleiermacher 1986:31-52) and apologetics to describe Christianity (Schleiermacher 1986:52-76). By using these 'borrowed propositions' Schleiermacher's notion of religious identity is not seen as the imposition of external truths (specifically by formal religious structures) but as religious propositions, dogmatics and doctrine developing subjectively in relation to a person's and community's ability to be conscious of self and to have an awareness of absolute dependence. 'This feeling [of immediate self-consciousness and absolute dependence, for Schleiermacher] defines the term God' (Root 1990:89). Religion therefore does not start with dogmatics, doctrine, confession or statements of belief but is based on concepts such as awe, mystery, vulnerability and the surrender of self to something other than self.

To start off with a notion of being conscious of self, Roy and Torrance (Roy 1997:225; Torrance 1968:279) identify three states of consciousness in Schleiermacher's anthropology. These are:

- the animal state (tierartig) - the awareness of self as a being (see Schleiermacher 2002:18)

- the sensibly determined state (sinnlich) - the awareness of self as a being that can 'feel' and is moved by these feelings (see Schleiermacher 1986:6)

- the state of absolute dependence (schlechthiniges or allgemeines Abhängigkeitsgefühl) ${ }^{4}$ (see Schleiermacher 1986:12, 19, 125).

Schleiermacher's notion of 'consciousness of self' is not the same as Feuerbach's definition. According to Feuerbach, consciousness in humanity is limited to the level of human existence, a consciousness and awareness confined by the ceiling of human self-understanding, concluding that God is, or must be, the highest form of humanity itself (Feuerbach 2012:1; Williams 1973:424-427).

Schleiermacher made a clear distinction between the self and the notion of God. The self becomes aware that it does not exist in isolation, but that its identity is subjective, moved by the other, leading the self to the conclusion that the self can only be authentically so by acknowledging its part in something bigger than itself (Schleiermacher 1995:81). Self-consciousness therefore fluctuates between being-forself (freedom) and coexistence-with-other (dependence) (Williams 1973:436). At the same time, freedom and dependence are not extremes but share an intimate connectedness (Schleiermacher 2011:135). If freedom originates from context, the human experience would operate in a closed system where true freedom is not possible.

Freedom is only truly experienced in relationship with and in dependence of the other (Williams 1973:440).

There is freedom in this absolute dependence in that human self-consciousness finds perspective in the awareness that the whole of our spontaneous activity comes from a source outside of us (Schleiermacher 1986:16-18).

Within the context of this free or dependent relationship, there is not only a relationship between God and the world and me and God, but also between me and my neighbour and me and the world. It is a communal relationship that helps the self to be conscious of its own existence and as a subject in absolute dependence of the other (Schleiermacher 1986:138-139). If I am dependent, then everything I encounter must also be dependent (Root 1990:91); therefore, as a self-conscious individual, I live in community with a world, people and environment that share my state of being.

Religious identity, as a subjective orientation towards being conscious of the self and dependence on the other, makes the act of being in community (with the other, with others and with the world) a religious experience. It is from the self-consciousness and feeling of absolute dependence that religious experience and identity flow.

Neitz and Spickard (1990) use two images to capture the generic nature of religious identity and experience. The first is to compare it to the stages of sexual arousal, stating that one needs some effort to get going, but then the body takes over naturally. The self needs the effort of becoming self-conscious and being in absolute dependence; once this is achieved, the experience naturally starts shaping one's view of reality, existentialism and transcendence. The second image is that of participating in an orchestra: participation in harmony results in a melodious experience which transcends the individual efforts of each musician. 'making religion' is therefore not a solo experience and it should never be a 'religion that fits the individual' or in Christian terminology, 
'creating God in our likeness'. Schüssler Fiorenza concurs by stating that 'In interpreting Schleiermacher, we need to avoid a humanistic as well as a fideistic interpretation' (Fiorenza 2000:24). For this reason, it should be noted that Schleiermacher referred to this form of religious identity, not as religie, but as Glaubensweise [a way of believing] (Fiorenza 2000:29; Schleiermacher 1986:30, 62).

Is this not the attraction offered by (the growing) practices of Yoga, meditation, mindfulness, Eastern religious meditations, grounding exercises and the like? Are they not helpful in assisting the individual to become centred in the moment; so to speak, to become aware of the self in this moment - in this space; and to acknowledge an intimate relational state with something more than oneself, with people and with the world? If this is the case, then yes, it would not be a great effort to move from being religious (being a subject of imposed doctrines and practices for the sustainability of an institution - a completely unnatural proposition) to being spiritual (being more self-conscious and aware of one's relational dependency; to feel grounded and connected - a natural inclination).

Kourie (2006) concurs that this is the motivating philosophy of movements in spirituality:

Some students of spirituality maintain that its main characteristics comprise relationships with things, nature, other people and the Ultimate (in whatever terms this is understood) as well as morality and integration, rather than being linked to religious practices. (p. 24)

So far, so good for a 'spiritual' person reading Schleiermacher. But there are two questions that persist to be a thorn in the flesh of the spiritual and the religious. These include: what to make of evil and how to understand Jesus.

\section{Making sense of evil}

Root asks the question: '[To Schleiermacher,] Is God the cause of both Christ and Genghis Khan?' (Root 1990:92-93). It is in answer to the question of the existence of evil that Schleiermacher introduces a teleological element in divine determination, namely, election. Of course, the term 'election' carries with it all kinds of understandings, stemming from Augustine and Calvin, among others. Schleiermacher uses the term in a different understanding: God decrees all things for the purpose of redemption (Schleiermacher 1986:536-545). Seeing that there is a distinct difference between God and the world, God does not interact with the world and therefore is not the causal ground for evil (Schleiermacher 1986:338-339). But, God opposes sin and evil, as is evident in the redemptive narrative of history, pointing to the elect state of a teleological, complete redemption from these 'problems' (Root 1990:97-100; Schleiermacher 1986:558-559).

Sin and evil exist in the world; this is an existential fact. It is a fact; It is experienced and as it is experienced, it forms part of the person's self-conscious experience of life - living in context and the absolute dependence on the other for its source of redemption. To speak about salvation, then, one can only say that 'Salvation is liberation from an evil suffered rather than reconciliation for an evil committed' (Root 1990:100). The implication is that redemption is redemption from the experience of suffering and the impact it has on the person. To Schleiermacher it is not to be misunderstood to mean the same as the imposed doctrine of the Christian religion (or any other religion) that advocates a redemptive state solely and purely outside of the lived experience. In the end, for Schleiermacher, 'The doctrine of election is an expression of the Christian sense that the self finally rests in every way on the God from whom comes every good' (Root 1990:104).

Once again, if there is a recognition of the existence of evil for the spiritual person, the reality of experiencing the impact of sin and evil and the hope that healing can take place in this life (and not exclusively in the afterlife), with the hope of the eradication of sin and evil as the final telos, then, it would once again not be difficult for such a person to read Schleiermacher.

\section{But what to make of Jesus ...?}

\section{The place of Jesus}

Schleiermacher confessed to being a Christian, even if the ideas he shared veered away from the classic interpretation of the doctrine of revelation as the starting point of God-consciousness, a doctrine deemed pivotal in shaping the other doctrines. He wrote The Christian Faith for Christians and hence shows his hand (Reynolds 2005:169) as a religiously biased commentator. Schleiermacher cannot move away from the person of Christ and must contend with all the associated questions, such as the two natures of Christ (see Schleiermacher 1986:391), the salvific efficacy of the person and work of Christ (see Schleiermacher 1986:68, 425), the incarnation (see Schleiermacher 2011:xvii) and so forth.

According to Schleiermacher, Jesus must be understood as a human in time and space, but as a human with a difference. Jesus is the person in history with the perfect Godconsciousness, which means that Jesus is the example of a person who had full self-consciousness and who had reached the ideal of absolute dependence on and in the other (Schleiermacher 1986:62, 361, 385). 'Christ is the one who reproduces God's pure act of love through his own God-consciousness. Christ, then, exists as pure activity and so, for Schleiermacher, is God incarnate' (Hector 2006:307). For Christians, the religious experience stems from the experience of redemption as an influence of Christ (Reynolds 2005:163).

When people become aware of their own consciousness and absolute dependence with Jesus as a reference point, a community that becomes a source of inspiration for others to discover their consciousness and absolute dependence is shaped. Revelation thus happens between people who seek genuine community, a community inspired by the person of 
Christ (Fiorenza 2000:20-21; Schleiermacher 1986:27-28). This community-based communication becomes the vehicle used by the Holy Spirit, 'drawing together and animating the historical life of the church as the common spirit of Christ' (Fiorenza 2000:27; Reynolds 2005:168; see Schleiermacher 1986:121-125, 560-581).

Does this mean that Schleiermacher is still a closed-exclusivist Christian? What about other religions? This is perhaps where Schleiermacher and the spiritual person may have to agree to disagree. If the person is 'spiritual' but grounded in the Christian faith, then perhaps not so. According to Schleiermacher, it is the person of Christ who enables the Christian faith to be elevated above other religions. All people have a tendency towards 'religiousness' (Reynolds 2005:152), indicating that this characteristic (a receptive organ of intuition and feeling) is our natural inclination to be in a relational state with the world, one another and the other. When this religiousness is formalised, it is:

mediated and cultivated via social and linguistic means, inexorably embedded in specific horizons of historical influence that modify its character in individual shapes. Each tradition takes a specific intuition of the infinite to be its centre and accordingly relates everything to it. (Reynolds 2005:157)

What distinguishes the Christian faith from other religions, except for the pivotal person of Jesus Christ, is the Christian faith's ability for self-criticism and openness to diversity within its own 'tradition' (see Reynolds 2005:165; Schleiermacher 1893:210-265). This is an important point because it indicates that religious identity is pliable and able to adapt to the nature of a person or community's self-consciousness and feeling of absolute dependence. This kind of faith still grows from the bottom-up, and is not imposed from the top-down. Of course, this excludes the Christian purists who, in Schleiermacher's view, occupy themselves with forms of idolatry, worshipping their structured faith instead of standing in awe of the other, who manifest in the existential and pragmatic outworking of God's gift of love (see Schleiermacher 1986:108-110).

Not only does Jesus become a central figure in a person's religious identity, but he also becomes the influence of a person's moral conduct. Here we draw back again to the idea of the other, the outward influence being able to move the person, as the person becomes aware of his or her own feelings and feelings of absolute dependence. This ethic shapes the person and the community to become a communicative ethic conveyed through language, the act of community, dependence and interdependence, unveiling our common sense of what is good and right and not just the 'what ought to be' (Schweiker 1999:187-188).

Christ redeems us by continuing the pure activity that constitutes his person: the act of receiving and reproducing God's act. In redemption, Christ draws us into blessedness by communicating this act to us and enabling us to reproduce this act as our own. (Hector 2006:319)

\section{Conclusion}

To identify as being 'spiritual but not religious' is not a far cry from Schleiermacher's description of this phenomenon of the universal ability for self-consciousness and absolute dependence. Perhaps our churches in South Africa will start drawing people in again if, instead of being diehard custodians of set institutional directed doctrines, they present a gospel that:

- facilitates the means for people to become conscious of their beings, feelings and experiences

- guides people into acknowledging the nature of our relational state (with each other, with the world and with God)

- emphasises the practical relevance of such a faith in the world in which we live (opposed to preaching a gospel that is transcendentally fixated).

In brief, this kind of faith does not contradict the gospel at all, but it gives new meaning to the Commandments: 'Love the Lord your God with your entire being (heart, mind, soul and strength), and love your neighbour as you love yourself'.

This kind of faith is both rationally defensible and practically legitimised because it draws people together, instead of using religious structures to force people apart.

\section{Acknowledgement Competing interest}

The author has declared that no competing interests exist.

\section{Author contributions}

I declare that I am the sole author of this research article.

\section{Ethical consideration}

This article followed all ethical standards for carrying out research without direct contact with human or animal subjects.

\section{Funding}

This research received no specific grant from any funding agency in the public, commercial or not-for-profit sectors.

\section{Data availability statement}

Data sharing is not applicable to this article as no new data were created or analysed in this study.

\section{Disclaimer}

The views and opinions expressed in this article are those of the author and do not necessarily reflect the official policy or position of any affiliated agency of the author. 


\section{References}

Barnard, M., 2019, 'NG Kerk se lidmate daal met 24,8\%', Beeld, 26 January, p. 7.

Behrens, G., 1998, 'Feeling of absolute dependence or absolute feeling of dependence? (What Schleiermacher really said and why it matters)', Religious Studies 34(4), 471-481. https://doi.org/10.1017/S0034412598004594

Bester, A. \& Müller, J.C., 2017, 'Religion, an obstacle to workplace spirituality and employee wellness?', Verbum et Ecclesia 38(1), 1-9. https://doi.org/10.4102/ ve.v38i1.1779

Bowden, J. \& Richardson, A. (eds.), 1983, 'Enlightenment', in A. Richardson \& J. Bowden (eds.), A New dictionary of Christian theology, pp. 179-180, SCM Press, London.

Emerson, M.O. \& Hartman, D., 2006, 'The rise of religious fundamentalism', Annual Review of Sociology 32(1), 127-144. https://doi.org/10.1146/annurev.soc.32. 061604.123141

Faix, T., Hofmann, M. \& Künkler, T., 2015, Warum ich nicht mehr glaube, SCM Brockhaus, Witten.

Feuerbach, L., 2012, The essence of Christianity, transl. G. Eliot, Digireads.com, Kansas City.

Fiorenza, F.S., 2000, 'Religion: A contested site in theology and the study of religion' Harvard Theological Review 93(1), 7-34. https://doi.org/10.1017/S0017816 000016643

Gerrish, B.A., 1984, A prince of the Church: Schleiermacher and the beginnings of modern theology, SCM Press, London.

Hector, K.W., 2006, 'Actualism and Incarnation: The high Christology of Friedrich Schleiermacher', International Journal of Systematic Theology 8(3), 307-322. https://doi.org/10.1111/j.1468-2400.2006.00216.x

Kourie, C., 2006, 'The "turn" to spirituality', Acta Theologica 8, 19-38.

Lawson, E.T. \& McCauley, R.N., 1993, 'Crisis of conscience, riddle of identity: Making space for a cognitive approach to religious phenomena', Journal of the American Academy of Religion 61(2), 201-223. https://doi.org/10.1093/jaarel/ LXI.2.201

Leonard, C., 2012, 'The slow and steady death of the Dutch Reformed Church', Mail \& Guardian, viewed 21 February 2019, from https://mg.co.za/article/2012-04-05the-slow-and-steady-death-of-dutch-reformed-church.
Neitz, M.J. \& Spickard, J.V., 1990, 'Steps toward a sociology of religious experience: The theories of Mihaly Csikszentmihalyi and Alfred Schutz', Sociological Analysis 51(1), 15-33. https://doi.org/10.2307/3711338

Reynolds, T., 2005, 'Reconsidering Schleiermacher and the problem of religious diversity: Toward a dialectical pluralism', Journal of the American Academy of Religion 73(1), 151-181. https://doi.org/10.1093/jaarel//fi008

Root, M., 1990, 'Schleiermacher as innovator and inheritor; God, dependence, and election', Scottish Journal of Theology 43, 87-110. https://doi.org/10.1017/ S0036930600039703

Roy, L., 1997, 'Consciousness according to Schleiermacher', The Journal of Religion 77(2), 217-232. https://doi.org/10.1086/489970

Schleiermacher, F., 1893, On religion: Speeches to its cultured despisers, transl. J. Oman, K. Paul \& Trench, Trubner \& Co., London.

Schleiermacher, F., 1986, The Christian faith, 2nd edn., H.R. MacKintosh \& J. Steward (eds.), T. \& T. Clark Publishers, Edinburgh.

Schleiermacher, F., 1995, On what gives value to life, T.N. Tice \& E.G. Lawler (eds.), Edwin Mellen Press, Lewiston.

Schleiermacher, F., 2002, Schleiermacher: Lectures on Philosophical Ethics, R.B. Louden (ed.), Cambridge University Press, Cambridge.

Schleiermacher, F., 2011, Brief Outline of Theology as a Field of Study, Edited by T.N. Tice, Westminster John Knox Press, Louisville.

Schweiker, W., 1999, 'Consciousness and the good: Schleiermacher and contemporary theological ethics', Theology Today 56(2), 180-196. https://doi.org/10.1177/ 004057369905600205

South Africa, 1996, The Constitution of the Republic of South Africa 1996, Act 108 of 1996, Government Printer, Cape Town.

Torrance, J.B., 1968, 'Interpretation and understanding in Schleiermacher's theology: Some critical questions', Scottish Journal of Theology 21(3), 268-282. https://doi. org/10.1017/S0036930600054429

Wikipedia, 2018, Friedrich Schleiermacher, viewed 29 October 2018, from https://en wikipedia.org/w/index.php?title=Friedrich_Schleiermacher\&oldid=864153550.

Williams, R., 1973, 'Schleiermacher and Feuerbach on the intentionality of religious consciousness', Journal of Religion 53(4), 424-455. https://doi.org/10.1086/486362

Wyman, W.E., 2005, 'Sin and redemption', in J. Mariña (ed.), The Cambridge companion to Friedrich Schleiermacher, pp. 129-150, Cambridge University Press, Cambridge. 